\title{
The Irish government and physical education in primary schools, 1922-37
}

\author{
CONOR CURRAN* \\ Trinity College Dublin
}

\begin{abstract}
A B S T R A C T. This article examines the treatment of physical drill as a curricular subject in primary schools in the Irish Free State in the period from 1922 to 1937. In particular, it assesses the reasons why its status as an obligatory subject was reduced in the mid 1920s. It will show that the availability of facilities, resources and teaching staff with suitable qualifications were all considerations, while some teachers were not physically capable of teaching the subject in the early years of the Irish Free State. In addition, a strong emphasis on the Irish language and the view that a reduced curriculum was more beneficial to learning meant that some subjects, including physical drill, were deemed optional. However, the decision to reduce the subject's status had not been supported by everyone and it was mainly the Irish National Teachers' Organisation which was behind the move. Following its reduction from an obligatory subject to an optional one as a result of a decision taken at the Second National Programme Conference in 1926, a lack of a clear policy on the subject became evident. By the early 1930s, the subject was receiving more attention from the Irish government, which made some efforts made to integrate the Czechoslovakian Sokol system into Irish schools. In examining conflicting views on how to implement the Sokol system, and the work of Lieutenant Joseph Tichy, the man recruited to develop it within the Irish army, this article also identifies the reasons why this method of physical training was not a success in Irish schools.
\end{abstract}

$\mathrm{I}_{\mathrm{t}}^{\mathrm{n}}$ n 2015, the World Health Organisation predicted that Ireland's population is set to become the most obese in Europe. ${ }^{1}$ Given the long-standing lack of significance afforded to regular physical exercise in the Irish primary school curriculum, this is somewhat unsurprising. For much of the twentieth century, physical education remained on the periphery of the curriculum in Irish primary schools and it was not until the 1970s that the Department of Education placed more emphasis on the role of the teacher in fostering its development. ${ }^{2}$ Despite some curricular

* School of Education, Trinity College Dublin, curranc5@tcd.ie

${ }^{1}$ Irish Times, 6 May 2015.

${ }^{2}$ Cork Examiner, 24 Nov. 1971; I.N.T.O., Primary school curriculum survey (Dublin, 1974), pp 17, 23. Although 'physical education' was generally not the term used by the Department of Education in the early years of the Irish Free State when 'drill', 'physical drill' and 'physical training' were more common, it is the contemporary term and it has been used in this article. In 1932, the title of the 'Revised notes for teachers: drill' was changed to 'Revised notes for teachers: physical training'. This followed a suggestion by Divisional Inspector Henry Morris who was involved in their drafting. He noted that the terms 'physical training', 'drill' and 'physical education' had been used in the draft text. 
improvements in the early part of that decade, physical education continued to be neglected. In August 1996, the results of an international study carried out by the European Union of Physical Education Associations illustrated that Irish primary pupils were at the bottom of a European physical education league, in terms of time given to the subject. Schoolchildren in France, Luxembourg, Portugal and Switzerland undertook three hours of physical education a week on average compared to the one hour allocated in Irish primary schools. ${ }^{3}$ The development of a mandatory system of physical education within Irish schools has been a slow process, and it was only in 2017 that the Department of Education announced that physical education would be piloted as a Leaving Certificate examination subject in a number of schools. ${ }^{4}$ This negligence on their part can be traced back to the mid 1920s, when the Department of Education made physical drill an optional subject in Irish primary schools. Despite repeated public calls for improvements to the status of the subject within the Irish primary school curriculum, physical education, as it became known, remained a neglected subject in many Irish schools for much of the twentieth century. ${ }^{5}$

While the history of sport has received considerable scholarly attention in recent decades, the crucial decision to downgrade physical drill has not been examined in any detail. Specialist works on physical education have noted the change but have said little about events at the National Conference Programme in 1925-6. Thomas A. O'Donoghue has assessed the Department of Education's policies towards sport in the period from 1926 until 1948. He notes that by the mid 1920s, 'most teachers were not competent to teach the subject', and that overcrowding of the curriculum and the desire to promote Irish were fundamental to the decision to reduce physical drill's status to optional. ${ }^{6}$ However, the precise means by which it came to be removed have not yet been fully examined. As will be seen, there was more support for its inclusion as a compulsory subject than has been noted. O'Donoghue has also assessed the attempt by the Department of Defence to introduce the Sokol system of physical training into Irish schools in the 1930s. ${ }^{7}$ Patrick Duffy, in his doctoral study of government policies towards physical education, focuses mainly on the years from 1960 until 1996. However, like O'Donoghue, he notes that the development of Sokol was rejected by Commander B. T. Coote, a member of

By the late 1930s, the term 'physical education' had become more common. See: 'Revised notes for teachers: drill: physical training in national schools, preparatory colleges and in training colleges', 9 Sept. 1932 (N.A.I., ED/12/31032); 'Physical education: the report of the committee, 1938 ', p. 8 (N.A.I., TAOIS/S11053).

${ }^{3}$ Irish Independent, 6 Aug. 1996.

4 'Taoiseach \& Minister Bruton announce examinable Leaving Certificate subject in physical education', 11 Dec. 2017 (https://www.education.ie/en/Press-Events/Press-Releases/ 2017-Press-Releases/PR17-12-11.html) (19 Dec. 2020).

${ }^{5}$ See, for example, Sunday Independent, 23 June 1957; Irish Press, 25 July 1962; Irish Independent, 29 Mar. 1949, 15 Nov. 1951, 18 Dec. 1989, 29 Jan. 1996.

6 Thomas A. O'Donoghue, 'Sport, recreation and physical education: the evolution of a national policy of regeneration in Éire, 1926-48' in International Journal of the History of Sport, iii, no. 2 (1986), p. 219.

7 Thomas A. O'Donoghue, 'The attempt by the Department of Defence to introduce the Sokol system of physical education into Irish schools in the 1930s' in Irish Educational Studies, v, no. 2 (1985), pp 329-42. 
the committee set up by the government to investigate physical education in Ireland in 1936, as he favoured the Ling system of physical training. ${ }^{8}$

Recent studies of the history of sport in relation to Irish childhood and adolescence focus largely on the development of clubs linked to political or religious organisations in the late nineteenth and early twentieth centuries. ${ }^{9}$ Ríona Nic Congáil has highlighted how Gaelic games were encouraged within the Irish Fireside Club, 'the largest children's association in Ireland in the late 1880s', through related newspaper columns written under the pen name of 'Uncle Remus'. ${ }^{10}$ In addition, she notes how Agnes O'Farrelly, a lecturer in University College Dublin, encouraged the Gaelic Athletic Association to introduce camogie in primary schools in the early twentieth century following the early success of the sport in universities and its diffusion into secondary schools through former students. ${ }^{11}$ A boys' hurling club, Na Fianna Éireann, was established by Bulmer Hobson in Belfast in 1902, with hurling, Gaelic football, history and Irish classes operational. ${ }^{12}$ As Marnie Hay has shown, Na Fianna Éireann was, despite its subsequent decline, the forerunner to the development of a more prominent version of the organisation bearing the same name which was also referred to as the Irish National Boy Scouts. ${ }^{13}$

The main focus of this article will be the two key developments in the treatment of physical education in independent Ireland in the period from 1922 to 1937. Firstly, following an overview of the state of physical drill in Ireland's schools in the pre-partition period, the article examines the decision to reduce the status of physical drill, from an obligatory subject to an optional one, at the Second National Programme Conference in 1925-6. The article shows that while there were mixed views on the value of physical drill in Irish schools, its removal as a compulsory subject ultimately came down to a vote by National Programme Conference members, with representatives of the Irish National Teachers' Organisation eager to reduce the number of obligatory subjects. The second key development involved efforts by the Department of Education to integrate the Czechoslovakian Sokol system of physical training into Irish schools in the following decade. The article argues that difficulties in communication, a lack of governmental support and an inability to develop a nationwide plan were the most significant reasons for the failure of this initiative.

Given the geographical and cultural links between Britain and Ireland, it was natural that codified sport would find its way into Irish educational institutes and

${ }^{8}$ Patrick Duffy, 'State policy on school physical education with specific reference to the period 1960-1996' (Ph.D. thesis, St Patrick's College, Maynooth, 1997), p. 58.

${ }^{9}$ See, for example, Maria Luddy and James Smith (eds), Children, childhood and Irish society: 1500 to the present (Dublin, 2014); Catherine Cox and Susannah Riordan (eds), Adolescence in modern Irish history (Basingstoke, 2015).

${ }^{10}$ Ríona Nic Congáil, "“Fiction, amusement, instruction": the Irish fireside club and the educational ideology of the Gaelic League' in Éire-Ireland, xliv, nos 1 \& 2 (spring/summer 2009), pp 92, 99.

${ }^{11}$ Ríona Nic Congáil, "'Looking on for centuries from the sideline": Gaelic feminism and the rise of camogie' in Eire-Ireland, xlvii, nos 1 \& 2 (spring/summer 2013), pp 179-80.

12 Marnie Hay, 'An Irish nationalist adolescence: Na Fianna Éireann, 1909-1923' in Cox \& Riordan (eds), Adolescence in modern Irish history, p. 103.

${ }^{13}$ Ibid., p. 106. 
schools, although this was not the only way it spread. In County Donegal, for example, other factors were more significant than educational structures: the desire to provide sport for shop apprentices; the presence of the military; seasonal migration; and the influence of cultural boundaries. ${ }^{14}$ In Tipperary, the activity of three schools with differing religious patronage was important in the early spread of cricket, so much so that from 1840 until 1880 it was 'unrivalled as a field sport' within the county. ${ }^{15}$ After a rugby club had been founded in Trinity College Dublin in 1854, the game was promoted in the Farra and Ranelagh schools in Westmeath by headmasters who had experience of the game at the university. ${ }^{16}$ Many educational establishments viewed sport as an important means of imparting discipline and self-restraint. Muscular Christianity, 'the belief that physical activity played a crucial role in developing Christian gentlemen', had become a strong part of the educational ethos in Britain and Ireland by the late nineteenth century. As Tom Hunt has noted, this resulted in a view that 'participation in sport taught courage, self-reliance and helped character building'. ${ }^{17}$ However, the desire for success was often a more prominent reason for developing a structure for sport. As Liam O'Callaghan has shown, with the development of inter-school competitions, in some areas, such as Limerick, 'the prestige of winning competitions was a far more palpable motivation'. ${ }^{18}$

By the late nineteenth century, gymnasiums and schools of physical culture had become more common in cities and towns, and some of the more prestigious schools pioneered the use of specialised equipment. ${ }^{19}$ As codified sports grew in popularity, games such as cricket and rugby became prominent in the Royal Schools in Ulster. ${ }^{20}$ Cricket was the first team game to be played by students at Blackrock College, in 1865, five years after its foundation by a French priest, Fr Jules Leman and his friends, and rugby followed in the $1870 \mathrm{~s} .{ }^{21}$ Advanced sports facilities remained a feature of private schools into the early twentieth century. For example, St Joseph's College, Ballinasloe, described as 'the St Enda's and the Skerry's of the provinces' in 1912, was advertised as having 'magnificent hurling and football fields, ball courts and recreation halls'. ${ }^{22}$ The Irish Independent also commented that it had 'the best equipped gymnasium in Ireland'. ${ }^{23}$

Brendan Walsh has noted an encouragement of scientific and practical subjects by educational theorists in the late $1800 \mathrm{~s}$, as 'Europe witnessed the rise of the kindergarten and associated movements and there was a general reassessment of the

${ }^{14}$ See: Conor Curran, The development of sport in Donegal, 1880-1935 (Cork, 2015), pp 163-70.

15 Pat Bracken, The growth and development of sport in County Tipperary, 1840-1880 (Cork, 2018), p. 189.

${ }^{16}$ Tom Hunt, Sport and society in Victorian Ireland: the case of Westmeath (Cork, 2007), p. 174 .

${ }^{17}$ Ibid.

${ }^{18}$ Liam O'Callaghan, Rugby in Munster: a social and cultural history (Cork, 2011), p. 118.

${ }^{19}$ See, for example, Coleraine Chronicle, 21 Mar. 1896.

20 See, for example, Londonderry Standard, 31 May 1865; The Anglo-Celt, 6 Oct. 1894.

${ }^{21}$ Sean P. Farragher, Blackrock College, 1860-1995 (Dublin, 1995), p. 18; 'Blackrock College: history' (https://www.blackrockcollege.com/about/history-of-blackrock) (14 Nov. 2018).

${ }^{22}$ Irish Independent, 10 Aug. 1912.

${ }^{23}$ Ibid. 
educative endeavour and, in particular, a desire to revisit the curriculum with a view to creating a balance between academic and practical subjects'. ${ }^{24}$ The Board of National Education initiated the Belmore Commission, also known as the Commission on Manual and Practical Instruction, in 1897 to assess the possibility of making changes to the primary curriculum in Ireland. Thomas Walsh has stated that 'it sought to replace the rigidity in the teaching and learning experience that had been introduced by the Payments by Results scheme and to broaden the curriculum'. ${ }^{25}$ As John Coolahan has written, this move was influenced by both childcentred and practical educationalists who challenged traditional ways of viewing the curriculum in elementary schools. ${ }^{26}$ This investigation resulted in the Revised Programme for National Schools, which brought the introduction of new subjects such as physical drill, singing, drawing and object lessons in 1900. Although the programme was underfunded, these subjects were taught 'in almost all schools and in a fairly satisfactory manner', while 'school life for many children became more varied and interesting'. ${ }^{27}$ As Duffy has asserted, the commission felt that physical exercises and drill had a positive impact on children's well-being and could help energise them, while it was also highlighted that discipline and posture could be improved through physical activity. ${ }^{28}$ Physical drill was to be mandatory in all schools which had teachers qualified to teach it, while it was also to be included in those that did not as soon as possible. Boys were to be given five lessons per week within an overall period of ninety minutes, while girls were to receive two lessons within a sixty-minute period. ${ }^{29}$

By 31 December 1901, physical drill was being taught in 8,439 or 97.1 per cent of primary schools. ${ }^{30}$ O'Donoghue has noted that the publication of $\mathrm{A}$ model course of physical training by the Board of Education in 1902, following consultation with the War Office, was important in the spread of information about the subject. ${ }^{31}$ This development was linked to the rejection of many potential British army recruits in the Boer War of 1899-1902. As a result, the Board of Education encouraged the appointment of military instructors by schools. ${ }^{32}$ Teachers were also given instruction in the subject by those with military experience and classes led by private instructors took place in some areas. ${ }^{33}$ As well as the perceived moral benefits, physical drill was utilised for the purposes of improving pupils' physical condition. $^{34}$ A decline in enthusiasm for teaching the subject was noted in some

${ }^{24}$ Brendan Walsh, 'History of education in Ireland' in idem (ed.), Education studies in Ireland: the key disciplines (Dublin, 2011), p. 49.

${ }^{25}$ Thomas Walsh, 'Concepts of children and childhood from an educational perspective 1900-1940: context, curriculum and experiences' in Ciara Boylan and Ciara Gallagher (eds), Constructions of the Irish child in the independence period (Basingstoke, 2018), p. 28.

26 John Coolahan, Towards the era of lifelong learning: a history of Irish education, 1800 2016 (Dublin, 2017), p. 27.

${ }^{27}$ Ibid., p. 29.

${ }^{28}$ Duffy, 'State policy on school physical education in Ireland', p. 17.

${ }^{29}$ Ibid.

${ }^{30}$ The sixty-eighth report of the commissioners of national education in Ireland: year 1901 (Dublin, 1902), sect. 1, pp 38-9.

${ }^{31}$ O’Donoghue, 'Sport, recreation and physical education', pp 216-17.

${ }^{32}$ Ibid.

33 See, for example, Cork Examiner, 28 Mar. 1901; North Down Herald and County Down Independent, 30 Nov. 1900, 1 Feb. 1901.

${ }^{34}$ Cork Examiner, 14 Dec. 1901. 
inspectors' reports by the beginning of the second decade of the twentieth century and facilities such as playgrounds were poor in many schools. Reporting on the Dublin Number Two Circuit in 1911, Inspector Dr T. J. Alexander stated that 'drill is often not taken with sufficient seriousness' and indicated that a lack of teacher training in the subject was part of the reason for this. ${ }^{35}$ However, it is important to note that physical drill did remain a compulsory subject at this point. By the beginning of the third decade of the twentieth century, the events of the Irish Revolution and partition meant that the island of Ireland would have two systems of primary education, and this article will now deal with that in the Irish Free State.

II

Following the signing of the Anglo-Irish Treaty the previous year, on the first day of February 1922, the new Irish government took control of education in the Free State. $^{36}$ The structure of departmental administration, finance and control 'remained very much as it had been under the British regime'. ${ }^{37}$ In January 1921, the I.N.T.O. had already convened a National Programme Conference to establish an educational programme for Irish primary schools. ${ }^{38}$ At the end of January 1922, T. J. O'Connell, the general secretary of the I.N.T.O., announced that a new programme was to be issued. Fionán Lynch, the minister for education, approved the programme and accepted it on behalf of Dáil Éireann and the provisional government. The programme was influenced by the input of Professor Timothy J. Corcoran of the National University of Ireland, a Jesuit priest, 'and several prominent teachers'. It comprised a number of obligatory subjects, as well as additional or optional subjects. Irish, English, mathematics, history and geography (now combined), singing, needlework (for girls) and drill were named as obligatory subjects. ${ }^{39}$ The National Programme Conference decided that only Irish would be used at infant level, while instruction in the history and geography of Ireland, singing and physical drill would be modified and conducted through Irish for all years. ${ }^{40}$ The new programme was to be implemented at the beginning of the following school year (1922-3) and it was noted that the ministry would undertake to provide 'facilities at the earliest possible opportunity' for the special training and equipping of teachers so that they would be able to deal with the programme. ${ }^{41}$ The previous programme had been criticised for having 'too many obligatory subjects' which meant that teachers did not have sufficient freedom, while teaching the

${ }^{35}$ The seventy-seventh report of the commissioners of national education in Ireland: year 1910-1 (Dublin, 1911), sect. i., p. 81.

${ }^{36}$ Coolahan, Towards the era of lifelong learning, p. 53. The Department of Education did not become operational until June 1924. It was established with Eoin MacNeill as minister for education following an order under the Minister and Secretaries Act 1924. See Report of the Department of Education for the school year 1924-25 and the financial and administrative years 1924-25-26 (Dublin, 1926), p. 5.

37 John Coolahan, Irish education: history and structure (Dublin, 1981), p. 39.

38 Ibid.

${ }^{39}$ Irish Independent, 2 Feb. 1922.

40 Ibid.; National programme of primary instruction: issued by the National Programme Conference (Dublin, 1922), p. 4.

${ }^{41}$ Ibid. 
Irish language had not been compulsory "except in a few "bilingual schools", 42 In general, the pre-independence programme 'was felt to be out of harmony with national ideals and requirements'. ${ }^{43}$ Following the issuing of a public notice related to the teaching of Irish on 1 February 1922, the National Programme of Instruction, a product of the National Programme Conference, was circulated to all national schools in April, along with a covering circular. ${ }^{44}$

The programme, coincidentally drawn up with the founder of the first camogie club in Ireland, Máire Ní Chinnéide, as chairperson, specifically stated that 'at least one half-hour per week should, in every school, be devoted to formal systematic instruction in Physical Drill', although 'two or three lessons of 15 or 10 minutes' duration' were 'preferable' with instruction 'in all cases to be given out of doors' ${ }^{45}$ The system to be used had been developed in Sweden although 'other approved systems' could be taken on. An emphasis was also placed on 'the manner and deportment of the pupils' with 'prompt obedience' essential. ${ }^{46}$ O'Donoghue has stated that by the end of the second decade of the twentieth century, promotion of the Swedish system of physical training had surpassed the system of military drill in Britain, so that the new British physical training syllabus for schools of 1919 'relied mainly upon the Swedish system and therapeutic exercises'. ${ }^{4}$

As Thomas Walsh has stated, the writings of Patrick Pearse and the work of the Gaelic League had a strong impact on the curriculum in the new Free State: 'there was an attempt by the church and State to revert to a romantic and mythical nation that pre-dated British occupation and the revival of the Irish language was central to this undertaking, ${ }^{48}$ While the Department of Education was in control of the content of the curriculum, the Catholic church, due to its influence in and management of many schools, was in 'a very strong position in terms of the ethos pervading in schools and in imbuing in children and parents a loyalty and deference to the church' ${ }^{49}$ The church's view of how a child should be raised 'formed a natural fit with cultural nationalist ideology and collectively these two ideologies dominated the educational discourse until the 1960s'. ${ }^{50}$ In addition, Coolahan has asserted that it was not until that decade that parents began to take on a more active role within the structure of Irish schools, despite the position afforded to them in the 1937 constitution in relation to the education of their children. ${ }^{51}$ O'Donoghue has highlighted how 'academic bias' also meant that sport was not seen as sufficiently worthy of pursuit in some Irish schools in the Free State. In support of this view, he has highlighted Taoiseach W. T. Cosgrave's admission in 1928 that public finance

42 Ibid., p. 1.

43 Ibid.

44 Áine Hyland and Kenneth Milne, Irish educational documents, ii: a selection of extracts from documents relating to the history of education from 1922 to 1991 in the Irish Free State and the Republic of Ireland (Dublin, 1992), p. 87.

${ }^{45}$ National programme of primary instruction, p. 14; Diarmaid Breathnach and Máire Ní Mhurchú, 'Ní Chinnéide, Máire (1878-1967)' (https:/www.ainm.ie/Bio.aspx?ID=2173) (16 Mar. 2019).

46 National programme of primary instruction, p. 14.

47 O'Donoghue, 'Sport, recreation and physical education', p. 219.

48 Thomas Walsh, 'Concepts of children and childhood', p. 31.

49 Ibid.

50 Ibid.

51 Coolahan, Irish education, pp 6, 172. 
should not be spent to promote it. ${ }^{52}$ Moreover, it appears that most parents were not interested in the development of a subject that was considered of less significance than the more important 'academic' disciplines.

Coolahan has noted that the report of the 1922 National Programme Conference 'was a slim document, primarily concerned with laying down attitudes and programmes for each class in each subject in the national schools ... very little attention was given to setting out the theoretical framework or curricular philosophy which was to guide the new programmes'. ${ }^{53} \mathrm{He}$ also states that 'the programme was a radical departure from that which had existed prior to independence and it became clear that the most important function of the school programme was the promotion of a knowledge of Irish'. ${ }^{54}$ This was despite the fact that only 1,100 of 12,000 lay national school teachers in the spring of 1922 had certificates in Irish and English. ${ }^{55}$ A number of subjects lost their status as obligatory subjects, including drawing, elementary science, hygiene, needlework (at a lower level) and nature study, as it was agreed that the curriculum was too crowded. ${ }^{56}$ As Thomas Walsh has stated, 'the tone and content of the programmes introduced in the 1920s moved away from the child-centred ideology and broad curriculum of 1900 and placed the restoration of the Irish language and the development of nationhood above direct pedagogical considerations'.57

\section{III}

In July 1924, following a debate on public education, the Dáil agreed that reform of the education system was necessary. ${ }^{58}$ Naturally, the place of physical training was part of the discussion. General Richard Mulcahy of Cumann na nGaedhael felt that the minister for education, Eoin MacNeill, was not doing enough to develop physical training. ${ }^{59}$ Mulcahy believed that 'a little consultation' between the minister for education and the Garda Síochána and military would be beneficial in order to provide physical training with the kind of 'systematic beginning' which was still necessary. ${ }^{60}$ MacNeill responded: 'I do not know, at the moment, how it should be done. However, I think I can say, and it is all I can say, that the matter of physical training will not be lost sight of. ${ }^{61}$ At the same time, he noted that, in relation to the state of many schools, 'physical existence is about as much as is possible in some of them'. ${ }^{62}$

In June 1925, MacNeill summoned a Second National Programme Conference to re-examine and report on the primary school programme. ${ }^{63}$ The conference met under the chairmanship of Fr Lambert McKenna and was comprised of three

52 O'Donoghue, 'Sport, recreation and physical education', p. 220.

${ }^{53}$ Coolahan, Irish education, pp 39-40.

${ }^{54}$ Ibid., p. 40.

55 Ibid., p. 41.

56 Ibid., p. 40.

${ }^{57}$ Walsh, 'Concepts of children and childhood', p. 38.

${ }^{58}$ Irish Independent, 4 July 1924; Dáil Éireann deb., viii, 418 (3 July 1924).

59 Ibid.

${ }^{60}$ Evening Herald, 8 July 1924.

${ }^{61}$ Dáil Éireann deb., viii, 579 (7 July 1924).

62 Ibid., viii, 578 (7 July 1924).

${ }^{63}$ Cork Examiner, 6 Apr. 1926. 
representatives of school managers, two representatives of national school teachers, three members of the I.N.T.O.'s Central Executive Committee, two representatives of the General Council of County Councils, two Gaelic League representatives and eleven nominees of the minister for education. Patrick Breathnach of the National Education Office acted as secretary. ${ }^{64}$ The conference was arranged mainly because of the difficulties experienced by teachers in implementing the curriculum. ${ }^{65}$ The conference received correspondence from fifty-four public bodies, 150 individuals and ' 1,250 teachers attending the special summer courses in colleges for the teaching of Irish' ${ }^{66}$ In addition to the written submissions, oral testimony was also recorded at the conference meetings. The conference held its final meeting and produced a report in early March $1926 .{ }^{67}$

The conference heard many positive voices in favour of the retention of physical drill as a compulsory subject. For example, Professor Timothy Corcoran stated that 'drill should exist for all' and that he was 'a strong advocate of the National organisation of games on the Primary school side'. ${ }^{68} \mathrm{He}$ added that 'anyone who has travelled the roads of Ireland as I have, and observed the average walk of the average farmer about 40 years of age, will see the need of physical training. ${ }^{69}$ Others appeared to lack any real understanding of the benefits of a structured system of physical training, with one Dublin-based school principal stating that 'the country has been sufficiently well drilled for some years back. The pupils might be encouraged to carry out some physical exercises at home. ${ }^{70}$ The issue of time in a crowded curriculum was an important consideration for some who made submissions, but the problem of facilities was also noted. One Cork principal stated that physical drill should only be obligatory where a playground existed. In his district, it had 'to be taught either in the school-room or on the public highway'. ${ }^{71}$ Critical comments by Adjutant General Aodh MacNeill also illustrate how the subject was viewed in some quarters. ${ }^{72}$ He stated that the present loose system of physical training in Irish national schools is practically criminal. It achieves no good results, and many bad ones, and is at best a mere sham., ${ }^{73}$

The status of physical drill in Irish primary schools came down to a vote taken by eleven conference members at a meeting on 17 November 1925 . Those at the meeting voted nine to two in favour of making the subject optional. ${ }^{74}$ The chairman,

64 'Notice relative to the National Programme Conference, published on the $4^{\text {th }}$ June 1925 ' (N.A.I., ED/12/12848).

${ }_{65}$ Coolahan, Irish education, p. 41.

66 'National programme reports for the Second National Programme Conference made for the information of the minister for Education (1925-26)', p. 2 (N.A.I., ED/12/12848).

${ }^{67}$ Irish Independent, 6 Mar. 1926.

68 'Letters from witnesses willing to give oral evidence at conference. Examining Sub-Committee of National Programme Conference, 22 Sept. 1925' (N.A.I., ED/12/12851).

${ }^{69}$ Ibid.

70 'Letters from witnesses willing to give oral evidence at conference. Evidence of $\mathrm{Mr}$ Timothy O'Brien, principal, St Michael and John's School, Dublin' (N.A.I., ED/12/12851).

71 'Digest of replies received in relation to the points on which information is specially desired by the National Programme Conference, 1925', p. 9 (N.A.I., ED/12/12850).

72 'Letters from witnesses willing to give oral evidence at conference. Memo. re. programme of primary education. Adjutant General Aodh MacNeill, 14 Aug. 1925' (N.A.I., $\mathrm{ED} / 12 / 12851)$.

${ }^{73}$ Ibid.

74 'National Programme Conference decisions, 1925-1926. Meeting of 17 Nov. 1925 and National Programme Conference, minutes of meetings on the $17^{\text {th }}, 18^{\text {th }}, 19^{\text {th }}, 20^{\text {th }}, 24^{\text {th }}, 25^{\text {th }}$ 
Fr Lambert McKenna, had initially stated that 'all evidence was in favour of it provided it did not take up much time. It was of a recreative character. ${ }^{, 75}$ Cormac Breathnach, a Gaelic League representative, said that he was 'in favour of it on condition that time be limited'. However, stronger opposition was voiced by some other conference members. Cornelius P. Murphy, the president of the I.N.T.O., noted that 'the [inspectors'] marking of teachers' efficiency' impacted on the status of subjects and that 'he was strongly in favour of leaving physical training amongst the optional subjects'. ${ }^{76}$ He stated that 'a man who can teach it will teach it even if it is optional'. ${ }^{77}$ Divisional Inspector Henry Morris felt that 'a good many teachers were incapable, owing to age and stoutness, of making the movements required for physical training and their instruction was therefore of little use'. ${ }^{78}$ Despite Brother Andrew A. Kelleher stating that 'the Christian Brothers were in favour of it', An Seabhac, Pádraig Ó Siochfhradha, the Irish language writer, who was representing the General Council of County Councils, thought that it should not be compulsory. He called for a members' vote on its status, with the overwhelming majority against it remaining obligatory, as noted above. ${ }^{79}$

In 1932, Divisional Inspector Henry Morris prepared a memo for the Department of Education in which he reflected on a number of issues in relation to the status of physical drill which had been discussed at the National Programme Conference in $1925-6 .{ }^{80}$ He noted the difficulties in teaching it outdoors, particularly in bad weather, 'unsuitable playgrounds' and 'the want of qualifications in the case of many teachers'. By 1932, he felt that efforts to make physical drill an obligatory subject again 'would raise difficulties with the INTO'. ${ }^{81}$ The fact that the I.N.T.O. president, Cornelius P. Murphy, probably voted to have the subject's status reduced in 1925 was unsurprising. The union's Central Executive Committee had written to the National Programme Conference earlier that year that 'the number of subjects which should be declared to be absolutely essential or obligatory in every school should be as few as possible'. ${ }^{82}$ The I.N.T.O. argued that 'the only subjects which should be declared to be obligatory are Irish, English and Mathematics, with Needlework for girls'. ${ }^{83}$

O'Donoghue has noted that with the deaths of Patrick Pearse in 1916 and Michael Collins in 1922, both of whom had shown a particular interest in physical education, little thought had been given by other revolutionaries to how the subject would fit into Irish primary school education or, more generally, 'the development of the Gaelic-minded man' in the years immediately after independence had been

and $26^{\text {th }}$ November $1925^{\prime}$, p. 4 (N.A.I., ED/12/12848). It appears that seventeen members were actually present and that 'the chairman and some other members' did not vote, although it is not clear why this was the case.

75 'National Programme Conference decisions, 1925-1926. Meeting of 17 Nov. 1925' (N.A.I., ED/12/12848).

${ }_{76}$ Ibid.

77 Ibid.

78 Ibid.

${ }^{79}$ Ibid.

80 'Revised notes for teachers' drill. Physical training in national schools, preparatory colleges and in training colleges. Memo of 9.9 .32 of chief inspector' (N.A.I., ED/12/31032).

${ }^{81}$ Ibid.

82 'Programme Conference, 1925. Statement submitted by the Central Executive Committee of the Irish National Teachers' Organisation' (N.A.I., ED/12/12850).

${ }^{83}$ Ibid. 
gained. ${ }^{84}$ An exception was General Richard Mulcahy, a member of the Second National Conference Programme, who engaged with the issue of physical drill during later meetings at which it was agreed that the subject, along with the issue of general health, would form the basis for further discussion. ${ }^{85}$ Other than this intervention, the status of the subject was amended without much debate. Mulcahy, however, also expressed his concerns in the Dáil in 1925. In November of that year, he raised the issue of introducing a more satisfactory system of physical training in schools and the related need to train teachers sufficiently to deal with the subject. He commented that 'a large body of teachers' were not taking responsibility for the physical training of national school pupils and added that "whether that may be another way of directing attention to the fact that they are dissatisfied with the inspectorial system or not, I do not know'. ${ }^{86}$ He felt that 'it is absolutely necessary that a systematised scheme of physical training should be obligatory throughout our national school course'. ${ }^{87}$ As Coolahan has stated, in the early years of the Irish Free State, 'relationships between inspectors and teachers were lacking in cordiality and co-operation', and a report into the inspection system in 1927 failed to resolve these matters. ${ }^{88}$

Mulcahy's comments regarding what he saw as the lack of teacher interest in promoting physical training in schools were rejected by T. J. O'Connell of the Labour Party, who was also a National Programme Conference member as well as general secretary of the I.N.T.O. He stated that teachers were aware of the issues relating to the subject. He believed that Mulcahy was forgetting the actual state of most of Ireland's schools, and was ignoring 'the possibilities of doing anything effective'. ${ }^{89}$ He added that 'it is all right, of course, to make arrangements for the physical training of children in large centres and in big schools'. However, he commented that most national schools were 'small schools of the type known as the two-teacher school' with only 600 out of 5,338 having three teachers or more. He added that 'in a typical small school in the country ... the atmosphere of the school is not suitable for the purpose of carrying out instruction in physical training'. Along with the conditions, O'Connell was of the view that school numbers and classroom management of varying ranges of ages were also problems, along with the physical fitness of some teachers. ${ }^{90}$ Eoin MacNeill, the minister for education, agreed with O'Connell's views on the inadequate environmental conditions for the implementation of physical training, but was reluctant to take any action. ${ }^{91}$ According to Séamus Ó Buachalla, the Cumann na nGaedheal government 'envisaged its role in education as one of minimal interference', while consolidation of the Irish Free State and financial stringency also had a strong influence on their decision making at the time. ${ }^{92} \mathrm{He}$ also has stated that the government's political stance and relations with the Catholic church 'combined to determine the nature of the

${ }^{84}$ O'Donoghue, 'Sport, recreation and physical education', p. 219.

85 'National Programme Conference decisions, 1925-1926. Meeting of 24 Nov. 1925' (N.A.I., ED/12/12848).

${ }^{86}$ Irish Independent, 18 Nov. 1925; Dáil Éireann deb., xiii, 458 (17. Nov. 1925).

${ }^{87}$ Dáil Éireann deb., xiii, 458 (17. Nov. 1925).

${ }^{88}$ Coolahan, Irish education, p. 49.

89 Ibid.

90 Ibid

${ }^{91}$ Ibid.; Irish Independent, 18 Nov. 1925.

92 Seamus Ó Buachalla, Education policy in twentieth-century Ireland (Dublin, 1988), p. 61. 
education policy' in the $1920 \mathrm{~s}^{93}$ Therefore, investment in the development of a national policy for physical education was certainly not a priority.

The status of physical drill at primary school level accordingly changed from 'obligatory' to 'optional' in $1926 .{ }^{94}$ More generally, the report of the National Conference Programme criticised attempts to teach Irish where teachers were inadequately prepared, and recommended the inclusion of rural science as an 'obligatory subject' (with exceptions in some schools) in the new programme. Irish, English, mathematics, history, geography, needlework (for girls), music, rural science (or nature study) were designated 'obligatory', while optional subjects included drawing, physical training, cookery (or laundry or domestic education) and manual instruction. ${ }^{95}$ It was reported that problems in restoring Irish 'as a vernacular' meant that the subjects chosen as obligatory had to be 'absolutely essential' only while 'there was a general feeling that the course had been too extensive hitherto'. ${ }^{96}$ Evidence from other countries suggested that 'concentrating on an essential minimum of subjects' was 'of recent years coming to be considered the preferable policy in primary education'. ${ }^{97}$ These subjects were also deemed to be optional due to 'the want of teaching power, or of material facilities, or of both together'. 98

According to the Department of Education's report for 1924-6, it expected that physical training would be taught in 'larger' schools, particularly those in urban areas, 'and also in a large number of our other schools where the teachers are competent to teach it and have the requisite facilities'. 99 The report also noted that 'the whole question of Physical Training should be considered at the earliest possible moment by the Departments of Education and of Local Government and Public Health'. This proposed development, which appears to be that recommended by General Mulcahy, was to be connected with a scheme for medical and dental inspection of pupils "with a view to the planning of a scheme of Physical Training calculated to improve the national health and physique by the application of simple systematic measures during the period of school life'. ${ }^{100}$ However, this scheme never came to fruition. MacNeill was replaced as minister for education by John Marcus O'Sullivan in 1926 and scarce efforts were made to improve physical education. O'Sullivan maintained the status quo until 1932, when Fianna Fáil came to power and Thomas Derrig took over as minister. ${ }^{101}$ In some areas, the official reduction of physical drill's status meant that it was almost completely neglected. One inspector's divisional report for primary schools in the area covering Cavan and Monaghan, and parts of Leitrim, Louth and Meath, in 1926-7 highlighted that since the subject had been made optional, "the teaching of drill has

93 Ibid

94 Irish Independent, 8 Mar. 1926.

95 Ibid.

${ }^{96}$ Report of the Department of Education for the school year 1924-25 and the financial and administrative years 1924-25-26, p. 25.

${ }^{97}$ Ibid.

98 Ibid.; Cork Examiner, 6 Apr. 1926. See also Hyland and Milne, Irish educational documents, ii, p. 105.

${ }^{99}$ Report of the Department of Education for the school year 1924-25 and the financial and administrative years 1924-25-26, p. 25; Cork Examiner, 6 Apr. 1926.

${ }^{100}$ Cork Examiner, 6 Apr. 1926.

101 Antonia McManus, Irish education: the ministerial legacy, 1919-99 (Dublin, 2014), p. 3. 
practically ceased'. ${ }^{102}$ A 1930 report on the same area, which by then also included portions of Westmeath and Longford, stated that 'drill as a subject of instruction is very rare'. ${ }^{103}$ It was later in this decade, after the change of government in 1932, that an attempt was made to rectify the provision of physical exercise in Irish schools.

\section{IV}

In 1933, the Department of Education published Notes for teachers: physical training, which discussed the strong role of the Swedish system in physical education in Irish schools. ${ }^{104}$ In a Department of Education circular issued that year in connection with this publication, the minister, Thomas Derrig, noted 'the importance of physical exercises in the schools'. ${ }^{105}$ His concern that they were 'not systematically taught in a larger proportion of the schools' was also expressed. ${ }^{106}$ Minister Derrig recommended that the teaching of physical training 'in the large schools' was to be 'entrusted to a member of the staff who has been trained within the last decade of years'. The effectiveness of teaching was to be judged by the deportment of pupils around the school and its grounds rather than their ability to carry out what were perceived by some to be awkward exercises. ${ }^{107}$ There was also some acknowledgement that physical training was not expected to be taught in every school; teachers 'in all schools, and especially in those where it was found not possible to give formal physical instruction' were expected to supervise pupils' postures and how they moved. Teachers were also urged to study the published notes on physical training, and to familiarise themselves with the recommended textbooks. ${ }^{108}$

The Department of Education's Notes for teachers contained sections on equipment, teaching an exercise, progression, children under seven, physical training's recreative side, dancing, dress, 'defective children' and health. However, the document illustrates the lack of a specific policy for the teaching of physical education in Irish Free State schools. The need for more development was noted by the authors, specifically when discussing the value of the Swedish system, although, surprisingly, they offered little on why physical training's place in the curriculum was neglected at the highest levels. While noting the dangers of its exclusion from schools, a lack of interest on the part of teachers was identified and the document commented that 'until similar work is taken up with enthusiasm in the National Schools of Ireland, we cannot hope to keep abreast of one of the best tendencies in modern education'. 109

102 Report of the Department of Education for the school years 1925-26-27 and the financial and administrative year 1926-27 (Dublin, 1927), p. 30.

${ }_{103}$ Report of the Department of Education 1929-30 (Dublin, 1930), p. 29.

104 An Roinn Oideachais, Oideachais náisiúnta - notes for teachers: physical training (Dublin, [1933]), pp 1-4.

105 'Revised notes on physical training' (Department of Education Archives, Cir. 4/33).

${ }^{106}$ Ibid.

107 Ibid.

108 Ibid.

109 An Roinn Oideachais, Oideachais náisiúnta - notes for teachers: physical training, pp 1-3. 
O’Donoghue has noted that between 1932, when Fianna Fáil took over in government, and 1939, when the Emergency began, 'there were a number of developments which seemed to indicate that physical education was going to be promoted to a central position in the programmes offered in primary, secondary and vocational schools'. ${ }^{110}$ One of these was an attempt to introduce the Czechoslovakian physical training system of Sokol into Irish schools, initially through its implementation as a form of training in the army. ${ }^{111}$ In particular, O'Donoghue sees the inclusion of a clause in the preliminary to the 1930 Vocational Education Act, in which physical training was included as part of a definition of a number of categories relevant to technical education, as a significant development prior to the move to develop Sokol. ${ }^{112}$ He has also stated that the Sokol system was chosen by the army because they believed that their physical training system was out of date at a time when they were also conscious of the threats posed by the Blueshirts and the I.R.A., in the early 1930s. ${ }^{113}$ In addition, Irish success at the 1932 Los Angeles Olympics, and the hosting of the Tailteann Games in Ireland that year, contributed to 'a year of awakening in physical education in Ireland'. ${ }^{114}$ The idea that the Irish army's participation in physical training in schools should increase also reflected military involvement in physical education in other European countries, particularly Italy and Germany. ${ }^{115}$

In January 1933, following correspondence the previous month, General Aodh MacNeill, the assistant chief of staff in the Irish army, addressed a minute to the director, No. 1 Bureau, Colonel F. McCorley, in which he expressed his desire to establish a scheme for fifty hours' training in physical culture. General MacNeill was of the opinion that the existing training regime was 'too stereotyped and unimaginative'. ${ }^{116}$ He wanted the new regime, which was to be prepared by the army's School of Physical Culture, to be less rigid and more varied, and gave instructions that a scheme would be set up to turn out suitably trained N.C.O.s. In addition, MacNeill requested an investigation of the finance resources available for the new scheme and he noted that the most modern training methods should be used. To that end, he asked for information on the methods used in Czechoslovakia, Germany and Sweden. ${ }^{117}$ Having completed enquiries into the methods of army training in other countries, in April 1934 the Department of External Affairs requested that the Czechoslovakian consul put arrangements in place to allow Lieutenant Joseph Tichy to take up the position of physical training instructor in the Irish army for one year. ${ }^{118}$

That same month, at the annual meeting of the Secondary Teachers' Association in Dublin, Major General Michael Brennan noted that the Irish army had decided to adopt the Sokol system. He commented that 'this was regarded as the best possible

${ }^{110}$ O'Donoghue, 'The attempt by the Department of Defence to introduce the Sokol system', p. 329.

111 Ibid.

112 Ibid.

113 Ibid., pp 337-8.

114 Ibid., p. 338.

115 Ibid.

${ }^{116}$ General Aodh MacNeill, Leathan Miontuairisce, to director, No. 1 Bureau, 3 Jan. 1933 (Military Archives of Ireland (hereafter M.A.I.), 2/32357).

117 Ibid.

${ }^{118}$ Lieutenant General Daniel MacCionnaith, chief of staff, to the minister for defence, 13 June 1947 (ibid.). 
for Saorstat needs' and that 'arrangements were practically completed for the introduction of that system in the army training schools and later throughout the country'. ${ }^{119}$ He acknowledged the Czechoslovakian consul's assistance and the success of the Sokol system at the 1932 Olympics. He noted the Irish army's intention to switch to this system, and stated that 'the days of the mechanical physical jerks were gone forever, as far as the Free State Army was concerned'. ${ }^{120}$ In June 1934, at an army shooting competition at the Curragh, the Czechoslovakian consul, Major Pavel Ruzicka, gave a lecture on Sokol before an audience which included the minister for defence, Frank Aiken, the minister for education, Thomas Derrig, and a number of army officers such as Lieutenant J. J. Hogan of the army School of Physical Culture. ${ }^{121}$ Major Ruzicka discussed 'the important part played by Sokols in the liberation of his country'. ${ }^{122}$ This reference drew comparisons with the G.A.A.'s involvement in the Irish Revolution from Aiken, who believed that once the system was up and running in the Irish army, with Lieutenant Tichy's help, 'it would lead to great achievements in the field of athletics'. ${ }^{123}$ However, he offered little detail on how the scheme would be implemented throughout the country.

A few days later, after a similar speech by the consul before a number of government and army representatives at Collins Barracks, Major General Brennan stated that he hoped that the Department of Education would cooperate in developing the Sokol system in schools. ${ }^{124}$ At that point, the Department of Defence had already been assisting the Department of Education in the development of physical training instructors for schools. ${ }^{125}$ Once the Sokol scheme was firmly in place in the army, it would be extended to schools, colleges and 'civilian gymnastic bodies'. ${ }^{126}$ Lieutenant Tichy took up his duties on 11 June 1934 . His first course began the following month and lasted until December; eleven officers attended. 127

In April 1935, Frank Aiken, during a Dáil discussion on the finances of the Irish defence forces, expressed his desire to see the Sokol system implemented, stating that 'it is hoped that in time we shall be able through the medium of Army instructors to introduce the system into our schools and colleges, and thus stimulate the physical development of the nation'. ${ }^{128}$ In July of that year, after watching 'the first public display of the new physical culture code' at the Curragh camp, Derrig described it as 'harmonious movement', while Aiken called it 'a magnificent system and a great improvement'. Dr John Burke of the Department of Education was of the view that it was ' $100 \mathrm{p}$ [er]. c c ent]. better' than the one being used, noting that 'the exercises are not too prolonged and there is constant change'. ${ }^{129}$ The

119 Cork Examiner, 4 Apr. 1934.

${ }^{120}$ Ibid.; Irish Press, 4 Apr. 1934.

121 Cork Examiner, 20 June 1934.

122 Ibid.

123 Ibid.

124 Evening Herald, 23 June 1934.

125 Ibid., 16 June 1934.

126 Ibid.

127 'Promotion of physical training in the army. Proposal to employ a continental (P.T.) expert. Information regarding P.T. in foreign countries. General Aodh MacNeill, Leathan Miontuairisce to director, No. 1 Bureau, 3 Jan. 1933' (M.A.I., 2/32357).

${ }^{128}$ Dáil Éireann deb., lv, 1798 (3 Apr. 1935).

129 Irish Independent, 16 July 1935. 
introduction of the system into the army and the public displays which followed resulted in 'widespread public interest shown in Sokol physical culture'. In December 1935 and again early in the new year, the lead instructor, Lieutenant Tichy gave a number of talks on the Sokol system on Radio Athlone. ${ }^{130}$ He was also involved in the preparation of the Department of Defence's two schemes, 'Education for health' and 'Scientific recreation for national development'. He also assisted in compiling four manuals, including one entitled 'Syllabus of physical education for schools'. ${ }^{131}$

However, implementing the system on a nationwide basis in schools proved difficult. At an address at the Military Barracks in Naas, County Kildare, in November 1936, minister for defence, Frank Aiken, urged more volunteers to take up the Sokol system and to spread it through the schools. He stated that there were enough volunteers and regular soldiers to train the young men of the country. ${ }^{132}$ The minister also felt that under the Land Act 1933, the Land Commission had the power to provide local clubs and authorities with land on which to carry out the training. ${ }^{133}$ Earlier that month, T. J. O'Connell commented that the Sokol system could be operational in 'the bigger centres of population, but that such instruction would be impracticable in the smaller schools'. ${ }^{134}$ The Irish Times noted that, at that point, the Department of Education had not come to a decision about which system would be most suitable for Irish schools, and, despite Aiken's later appeal, efforts to implement Sokol in them were sporadic in nature. ${ }^{135}$

Despite this indecision, there were some attempts to introduce the Sokol system in Irish schools. By April 1937, having been adapted slightly 'to suit the Irish technique and temperament', one newspaper reported that it was being taught by army instructors trained in the method in 'a large number of Irish schools and colleges' throughout the Free State, although no figures were given. These did, however, include St Patrick's Training College, Drumcondra and Coláiste Caomhin, Glasnevin. ${ }^{136}$ It would appear that it was mainly taught in second-level schools; the Irish Press identified eleven of these in Dublin, Mallow, Mullingar, Multyfarnham, Newbridge, Ballinasloe and Galway. ${ }^{137}$ In County Donegal, an effort was made to initiate the Sokol system in eight primary schools around Donegal town, under the guidance of Corporal McIntyre of the Donegal Sluagh. ${ }^{138}$ He had been trained in the system at the School of Physical Training in the Curragh camp. Soldiers were also involved in teaching the Sokol system in Letterkenny, Inver and Buncrana. Following an experimental period, one Donegal newspaper reported that arrangements were in place to extend Sokol to all Donegal schools, with more soldiers to be trained in the required methods at the Curragh. ${ }^{139}$ By March 1937 the same newspaper reported that Sokol was 'proving very interesting' and 'very successful' in the schools where it was

${ }^{130}$ Irish Press, 5 Dec. 1935, 28 Jan., 4, 5 Feb. 1936.

131 O'Donoghue, 'The attempt by the Department of Defence to introduce the Sokol system', pp 335-6.

${ }^{132}$ Irish Press, 18 Nov. 1936.

133 Ibid.

134 Irish Times, 10 Nov. 1936.

135 Ibid.

136 Irish Press, 10 Apr. 1937.

${ }^{137}$ Ibid.

${ }^{138}$ Donegal News, 23 Jan. 1937; Irish Press, 10 Apr. 1937.

139 Donegal News, 23 Jan. 1937. 
established. ${ }^{140}$ By the end of the decade the system had not, however, been fully implemented throughout the country. ${ }^{141}$ O'Donoghue has stated that its failure in Donegal resulted from an inadequate level of finance, while in Athlone, where it had apparently been first introduced into Irish schools, the transfer of soldiers hindered its development, and it is likely that that this reason was a factor too in other areas. ${ }^{142}$

Communicating and teaching the methodology of Sokol in Irish schools was clearly difficult. There are strong claims in Lieutenant General Daniel McKenna's account of physical training, forwarded to the minister for defence in 1947, that Lieutenant Tichy's level of English was initially poor and was 'a great obstacle to progress' on the first course he taught in $1934 .{ }^{143}$ McKenna also stated that the translation of manuals 'had to be done after hours, and was consequently slow'. ${ }^{144}$ While it was initially intended to translate twelve manuals, Tichy eventually completed the translation of only four into English, with copyright issues also problematic. The manuals apparently consisted of only 'a bare outline with virtually no explanation and could only be understood by a person who had already qualified in physical training'. ${ }^{145}$

Lieutenant Tichy's contract had been extended until June 1936 and 'during the last year he was principally engaged in translating manuals and in training personnel for the Physical Training displays at the Military Tattoo'. ${ }^{146}$ In Tichy's defence, his work was praised by the chief of staff, Major General Brennan, who stated that his work had justified his selection and noted 'the successful completion of the task' in a letter to the Czechoslovakian prior to his departure. ${ }^{147}$ In addition, Tichy's efforts in the organisation of the Military Tattoo of 1935 were commended, as was his translation of physical culture texts. There was little comment, however, about how well the Sokol system had been received by those trained by Lieutenant Tichy or its subsequent development, although his role in its initiation was commended. ${ }^{148}$ Financial considerations further hampered Sokol's development in Irish schools. In January 1936, Seamus Brennan, superintendent in the Central Office of the Primary Education Branch of the Department of Education, stated that the main difficulty in organising any scheme for physical training in schools would be 'the heavy cost of financing it'. ${ }^{149}$

The leaders of sporting organisations did not participate in the Second National Programme Conference, which did little to help the cause of sport in the primary

140 Ibid., 27 Mar. 1937.

141 Irish Press, 31 Jan. 1939.

142 O'Donoghue, 'The attempt by the Department of Defence', p. 337.

143 'Promotion of physical training in the army. Proposal to employ a continental (P.T.) expert. Information regarding P.T. in foreign countries. Lieutenant General Daniel McKenna, Chief of Staff, to the minister for defence, 13 June 1947' (M.A.I., 2/32357).

144 Ibid.

145 Ibid.

146 Ibid.

147 'Promotion of Physical training in the army. Proposal to employ a continental (P.T.) expert. Information regarding P.T. in foreign countries. Major General Brennan to Lieutenant Joseph Tichy, 10 June 1936' (M.A.I., 2/32357).

148 Ibid.

149 Irish Press, 15 Jan. 1936, 6 Feb. 1937. 
school curriculum. While the decision to reduce the status of physical education was taken by members of the Second National Programme Conference, there is some indication that it reflected the mixed engagement of teachers with the subject. As Mulcahy indicated, there was conflict between some teachers and department inspectors over the expectations concerning physical education in the mid 1920s, and this was a factor in the change of status. It is also apparent that some teachers lacked the training or physical ability to teach the subject to a satisfactory level. The resources available in many schools, particularly in rural areas, discouraged its teaching, not to mention the lack of a clear government policy, which resulted in some schools actively developing their own schedules to oversee its implementation. While the 1933 Notes for teachers: physical training did offer instructions on teaching, the content also alluded to its neglect.

By the mid 1930s, there was more awareness of the need to organise a comprehensive structure for the teaching of physical training in schools. In some areas, the Department of Education organised army instruction in the subject for teachers, but a more widespread effort to implement the Sokol system was hampered by organisational difficulties. Although Lieutenant Tichy's grasp of the English language probably did not help those he was training, the Sokol system failed due to a range of factors including the voluntary nature of the implementation; poor planning; lack of sufficient finances; and, at a more specific level, the mobility of some of the soldiers involved in teaching the system. Despite the problems, Sokol displays by the army were still highly popular in some areas in the late 1930 s and it continued to be taught in some schools. ${ }^{150}$ In late 1936 , the government appointed a committee to investigate the state of physical education, which had the potential to mark a significant development. ${ }^{151}$ However, the results of this investigation, along with two related reports during the war years, failed to gain sufficient backing at governmental level. ${ }^{152}$ While the Emergency undoubtedly hindered plans to develop physical education in Irish schools, concerns over finances, training and organisation were also significant. ${ }^{153}$

It was not until the 1960 s, a decade generally acknowledged as being crucial in the transformation of the education system in the Republic of Ireland, that the government undertook significant action to amend the status of physical education. In January 1963, it was announced that Patrick Hillery, minister for education, planned to appoint an inspector 'to control physical education in the schools' and to 'co-ordinate all present systems and plan future programmes'. ${ }^{154}$ By the early 1970s, the government had accepted the recommendations of the first inspector of physical education, Captain Michael McDonough. This was reflected in the revised primary curriculum of 1971, while the establishment of the National College of Physical Education in Limerick in 1973 meant that a specialised institution for secondary school teachers was finally operational. ${ }^{155}$

${ }^{150}$ See, for example, Limerick Leader, 20 Aug. 1938.

151 Connacht Telegraph, 8 Oct. 1938.

152 'Physical education: the report of the committee, 1938', p. 1 (N.A.I., TAOIS/S11053).

153 'Report of the committee appointed by the government to examine the question of the promotion of the revival of athletics, 1939', p. 1; secretary for the minister for education to the secretary of the taoiseach, 9 Jan. 1943 (N.A.I., TAOIS/S11053).

${ }^{154}$ Evening Herald, 30 Jan. 1963.

155 Cork Examiner, 24 Nov. 1971, 2 May 1973. 